\title{
Retraction Note: Evaluation of solar energy potential based on target detection and design of English vocabulary teaching platform
}

Yan Jin ${ }^{1}$

Published online: 4 November 2021

C) Saudi Society for Geosciences 2021

Retraction Note: Arabian Journal of Geosciences (2021) 14: 1494

https://doi.org/10.1007/s12517-021-07726-8

The Editor-in-Chief and the Publisher have retracted this article because the content of this article is nonsensical. The peer review process was not carried out in accordance with the Publisher's peer review policy. The author has not responded to correspondence regarding this retraction.

The original article can be found online at https://doi.org/10.1007/ s12517-021-07726-8.

Yan Jin

hbb45432@126.com

1 Foreign Language School, Changsha University of Science and Technology, Changsha 410114, China 